\title{
On Differences between General English Teaching and Business English Teaching
}

\author{
Wenzhong Zhu \\ School of English for International Business \\ Guangdong University of Foreign Studies \\ N.2 North Baiyun Avenue, Guangzhou 510420, China \\ Tel: 86-20-3631-7183 E-mail: wenzhong8988@sina.com
}

Fang Liao

School of English for International Business

Guangdong University of Foreign Studies

N.2 North Baiyun Avenue, Guangzhou 510420, China

Tel: 86-20-3620-4324

The research is financed by Guangdong University of Foreign Studies No. 2006-TB-013(the Innovation Research Program "Research on the Approach and Practice for the Teaching of Business English")

\begin{abstract}
With the accelerating rate of globalization, business exchanges are carried out cross the border, as a result there is a growing demand for talents professional both in English and Business. We can see that at present Business English courses are offered by many language schools in the aim of meeting the need for Business English talent. Many researchers argue that no differences can be defined between Business English teaching and General English teaching. However, this paper concludes that Business English is different from General English at least in such aspects as in the role of teacher, in course design, in teaching models, etc., thus different teaching methods should be applied in order to realize expected teaching goals.
\end{abstract}

Keywords: Business English, Globalization, ESP, Teaching methods, Teaching model course design

\section{Introduction}

With the growing demand for English courses tailored to specific needs, new ideas began to emerge in the study of language. Traditionally the aim of linguistics had been to describe the rules of English usage; however, the new studies shifted attention away from defining the formal features of language usage to discovering the ways in which language is actually used in real communication (Widdowson 1978). This phenomenon, along with the new developments in educational psychology, contributes to the rise of ESP (English for Specific Purposes). Business English is an area of ESP, and must be seen in the overall context of ESP, as it shares the important elements of needs analysis, syllabus design, course design, and materials selection and development which are common to all fields of work in ESP. However, Ellis and Johnson (2002) state:

'Business English differs from other varieties of ESP in that it is often a mix of specific content (relating to a particular job area or industry), and general content (relating to general ability to communicate more effectively, especially in the business situations)'

There have been many developments in the ways in which teachers and course designers look at Business English. In the late 1960s and early 1970s, special vocabulary was considered as what distinguishes Business English (BE) from General English (GE). A second approach placed a greater emphasis on training "the skills of communication in English speaking, writing, listening and reading within a business context". In the mid-1970s and 1980s, following the trends in GE, BE teaching began to focus more and more on functional areas-formulaic language for recommending, giving 
opinions, showing agreement, and so on. During the 1980s the development of company training programs began to provide employees with opportunities to attend courses in presentation techniques, negotiating, and effective meetings skills, which led to the publication of books and materials on business skills.

In China, business English can be traced back to the earliest era of 1950s, when high education institutions started to set Foreign Trade English course which mainly included such core courses as electronic communication English, selected readings of the Western paper, and oral English of foreign trade etc. In 1990s, going along with the globalization of Chinese economy and the rapid increase of foreign trade volume, talents of business English had become increasingly popular. As a result, business English began to replace foreign trade English. For example, in Guangdong University of Foreign Studies, a new school called the School of English for Business specializing in teaching business English undergraduate and postgraduate programs was established with the integration of teachers from Faculty of English Language and Culture, School of Law, and School of International Trade and Economics. At present, BE is highly recognized in the society as one of the most popular disciplines. Statistics shows that the number of universities that offer major business English courses exceeds 800, and the majors and degrees are increasingly diversified.

Therefore, in line with the growing popularity of BE, it is of great significance to study on the difference between GE teaching and BE teaching.

\section{Differences between GE teaching and BE teaching}

\subsection{Differences in the Role of Teacher}

The role of language teacher has developed from a director and model in traditional language teaching to a facilitator in contemporary language teaching (Shulin Liu et al 2004). To a large extent, the function and the methodology or approach the teacher performs in different teaching activities determines the role of the teacher. Both GE and BE teacher should be able to identify the current language level of the learner and to select materials and set tasks that are appropriate in level as well as in context. They also need to be able to set course objectives and devise course program. In order to achieve this it is essential for the teacher to have an in-depth knowledge of the language system in terms of skills functions, structures and vocabulary.

Business English teacher, as a language teacher, should perform the basic functions required for a language teacher, specifically as organizer, assessor, prompter, participant, controller as well as knowledge-resource. However, to be a qualified Business English teacher more is needed. Swales (1985) prefers with some justification to use the term 'ESP practitioner' rather than 'ESP teacher' in order to reflect the difference for being a ESP teacher from being a GE teacher. In $\mathrm{BE}$ we tent to use the term $\mathrm{BE}$ trainer, because some $\mathrm{BE}$ trainers come from a business background, who have worked in companies themselves and have useful knowledge of the way in which companies are organized and run, and some may once be TEFL teachers, geologists or architects etc. Whatever the background, it is of great importance that the trainer should be seen as an expert in presenting and explaining the language, in diagnosing the learners' language problems, and in providing them with certain awareness of Business English.

Besides the qualifications and a background in business, a right balance of personal skills carries the same weight of importance. For a BE trainer, it is preferable to have an outgoing personality, to be interested in interaction with people of a wide variety. It is important for the trainer to establish his or her credibility and professionalism to be able to discuss with the learners about the course. Furthermore, BE trainers need to be curious about and interested in all aspects of business, because one of the best way for the trainers to unlock the learners motivation and learning potential is to show that he or she can relate to the questions of learner, such as how the companies work, the organization procedures, marketing strategies, financial planning, problem-solving, new technical developments and new products launching.

\subsection{Differences in Course Design}

Course design is the process by which the raw data about a learning need is interpreted in order to produce an integrated series of teaching-learning experience, whose ultimate aim is to lead the learners to a particular state of knowledge. In general, the course design for GE focuses on subjects related to culture, literature, and linguistics, while that of BE focuses on courses related to the application of language in business communication. According to Hutchinson and Waters(2002), there are three main approaches to ESP course design, respectively called language-centered course design, skills-centered course design and learning-centered course design.

Language-centered course design, the simplest and most familiar one, aims to draw as direct connection as possible between the analyses of the target situation. It seems to be very logical, however, static and inflexible, only at the surface level.

Skills-centered course design has been widely used in a number of countries, especially in Latin America. This approach is founded on two fundamental principles, one theoretical, the other pragmatic. A skills-centered approach aims to get away from the surface performance data and look at the competence that underlies the performance. 
Comparatively speaking, this approach claims to take the learners more into account than the language-centered approach.

Learning-centered approach, different from the first approach -- language-centered approach, in which the learner is discarded, and the skills-centered approach which doesn't take the learner into full account, gives the most concern to the learners, thus to maximize learning.

BE, as a kind of developed ESP, can undoubtedly adopt the way of course design for ESP. Based on what is talked above, the third approach ---learning approach may be the best to assist in BE teaching activity, since it is most learner-centered, because BE learners usually have very clear demand for what to be learned, and some of them have set goals, especially the job-experienced learners. So it is important and necessary to take the students' practical need into consideration in BE teaching to make the learners benefit most from the class.

\section{Differences in teaching models}

Traditionally, teaching and learning was thought of as an "instructional paradigm" which the teacher as a dispenser of information in 45-or-50-minute lectures and the student as a passive receiver, container and repeater of the transmitted information. Teaching and learning was viewed as a linear process of information transfer and reception. For GE teaching, there are several teaching models frequently applied (Liu Yumei \& Xiao Bang, 2007).

\subsection{PPP Model}

PPP Model refers to the "presentation-practice-production" paradigm. At the Presentation stage, new grammatical structures are presented in meaningful contexts. At the Practice stage, learners are given a variety of practice tasks to reinforce what has been learnt. At the Production stage, learners are given practice tasks less controlled by the teacher to link what is newly learnt with what has been learnt before. In this model, the teacher plays a dominating role.

\subsection{ESA Model}

ESA Model (J. Harmer,1998) refers to the "engage-study-activate" paradigm. During the Engage phase, the teacher tries to arouse the students' interest and engage their emotions. During the Study phase, activities are carried out to focus on language or information and how it is constructed. In the Activate stage, the exercises and activities are designed to get students to use the language as communicatively as they can. This model seems to place more stress upon the students' cognitive and affective factors such as interest, curiosity and attention.

\subsection{PPT Model}

According to Ur(1996), the process of teaching a foreign language can be roughly broken down into three components: Presentation, Practice and Testing, as is called PPT Model. The function of the first and second stage of this model is more or less the same to PPP Model. In the third stage, a test may be designed to check what has been mastered and what still needs to be learned or reviewed.

In comparison, in $\mathrm{BE}$ teaching three different models are usually applied.

In the first model, BE is taught as a type of ESP, and a model of English for Occupational Purposes is adopted. This model starts with the students' need, and cultivates the students' basic ability, both in language and in behavior, required by the target business circumstance, for instance, in accountings, negotiations, marketing, business contract, etc.

The second model can be characterized as "content-based language instruction", which has been practiced in many European universities for BE teaching. Basically it has two stages. In the first stage, English is used as a tool to teach general business topics, such as enterprise, human resource management, stock exchange, international trade, economy theory etc. In the process, business communication skills training is offered, including how to write business correspondences and business memos. In the second stage, English international trade courses are offered, and the students are required to accomplish all these courses thus to gain the qualification to attend advanced seminar-oriented course of business.

The third model is a model of real-life situation planning, in which business material is adopted as the course content. The students are supposed to gain competence in the language used in those business communications. This model will be illustrated in detail in the following parts.

\section{Differences in teaching skills}

Traditionally, English is viewed as several components, called speaking, writing, listening, translation, and interpretation, and different teaching skills are applied in teaching each part. However, BE can not be treated in the same way, because BE learners are supposed to gain a comprehensive mastering of English required by business communications. It is hard to draw a line between the components, say, speaking, listening and writing, so traditional teaching skills may not be favorable in BE teaching. For this part focus is mainly placed on BE teaching skills, through which the difference between BE and GE teaching skills can be easily drawn. 
Suggested by Ellis and Johnson (2002), basically there are two methods of planning the course in BE teaching. The first is to take each of the main performance areas and break it down into constituent parts: skills components, language functions and the grammatical and lexical constituents. The second is to analyze the language used taken from real life situations, or from simulations of real life situations. Different teaching skills are needed in accordance with different course content planning. The two methods can be illustrated respectively along with the teaching skills desired as follows.

\subsection{Breakdown planning and its teaching skills}

Breakdown method functions much similarly to the teaching method used in GE, as it stresses on language, and its grammatical components, but its skills components and the lexical components bear differences from GE. Due to the difference on lexical level, GE words are widely used in business with another meaning in BE. BE teacher should spend more time on this point to cultivate the basic skills for the learners and make the business meaning of the lexical components clear to the learners. For example, 'minute', in GE, means 'one sixth part of an hour, equal to 60 seconds' indicating the time, however, it means 'a brief summary or record of what is said and decided at a meeting' in BE, absolutely different from the GE meaning; 'round' means 'shaped like a circle or a ball' in GE, but '(of a meeting) in which the participants meet more or less as equals' in BE. The following table (see Table 1) gives more examples:

BE teachers are supposed to pick up these words which contain different meaning particularly used in BE, and make the learners aware of that difference. Besides the teacher may further organize a discussion based on a certain topic. For instance, regarding the word "minute" appearing in the text with special meaning in Business English usage, related questions, such as what should be done before, during and after a meeting, may be thrown to students to arouse their awareness of certain business practice, and the students also need to make a research into the process of a business meeting, and to simulate a business meeting in the class. The following is a list of the language functions relating to controlling a meeting (Ellis and Johnson, 2002):

--opening the meeting

--nominating topics for discussion

--rejecting topics

--asking people on the subject

--postponing a topic

--coming back to a topic

--referring to time

--summarizing, restating, or the rephrasing

--concluding

--closing the meeting.

In identifying the appropriate choice of expression for carrying out these functions, a key parameter will be formality versus informality (for example, 'I declare this meeting open'; 'Right, let's get started').

Thus, it is suggested that BE teachers should spend more time on these differences between GE and BE meanings in order to cultivate the basic skills for the learners and make the business meaning of the lexical components clear to the learners.

\subsection{Real-life situation planning and its teaching skills}

This method of planning the content of course, using the language used in samples taken from different real-life situations or simulations of them, is widely applied in BE content planning. As we notice, many BE books are compiled in this way, covering areas such as financing, foreign trading, payment, negotiation and so on, to show the characteristics of language used in different business situations. Real-life situation planning undoubtedly is a preferable way in BE teaching, because it gives the students the most direct impression on how BE language is different from GE language. This method helps the student manage BE usage better and faster. The following dialogue can best illustrate this point. (Chen Dan, et al 2007):

A: Let's talk about the mode of payment, ok?

B: Yes.

A: Do you accept D/P? For such a large amount, a L/C is costly.

B: Since the total amount is so big and the world monetary market is still rather unstable at the moment, we adhere to $\mathrm{L} / \mathrm{C}$.

A: In order to conclude the business, I hope you will meet me halfway. What about $50 \%$ by $\mathrm{L} / \mathrm{C}$ and the balance by 
$\mathrm{D} / \mathrm{P} ?$

B: In view of our long friendly relations, we agree to your requirement this time, that is $50 \%$ by $\mathrm{L} / \mathrm{C}$ at sight and the balance by $\mathrm{D} / \mathrm{P}$ at sight.

A: Thank you for your close cooperation. And I sincerely hope that the volume of trade between us will be ever greater in future.

B: I hose so, too.

This is a typical businesslike dialogue, concerning the terms of payment in foreign trade. From the above dialogue, we can see that many special terms are used in the intercourse, such as monetary market, volume of trade, some of which are acronyms, such as $D / P, L / C$, and some of which are just GE words, yet containing special business meanings, such as balance, halfway and at sight. In a business communication it is quite common to encounter special terms concerning all the aspects of business.

Teaching this part, BE teachers had better get to know the procedures of the business concerned ahead of class, to help in teaching activity. Moreover, teachers are required to arouse learners' interest in and attention to the special usage of $\mathrm{BE}$, and to encourage them to practice for the purpose of mastering $\mathrm{BE}$.

\section{Conclusion}

Based on the analysis above, we know that the term BE is used to cover the English taught to a wide range of professional people, and people still in full-time education preparing for a business career and due to the special quality of BE, attention should not only be paid to language, but equally to the importance of skills-training in the teaching activity. This presents a tough challenge for BE teachers, as they are required to not only be professional in language, but also to develop awareness of the needs and concerns of business people and to become flexible enough to respond to those needs.

There is no 'best' methodology---any teaching situation is an interaction between the learner, the trainer and the activity itself. As a general rule, methodologies which put the learner at the center of the learning process are likely to be the most effective. In BE teaching activity, methodologies which combine language and real situation together discussed in this essay would be more favorable. Emphasis on the application of language in business communication can assist in the teacher carrying out the course more successfully and help the learners learn more quickly and more effectively--that can be a win-win policy.

\section{References}

Chen Dan et al. (2007). Speaking Business English in Different Ways. Beijing: China Water and Electricity Press.

Defense Industry Press.

Education Press.

Ellis, M. \& Johnson, C. (2002). Teaching Business English. Shanghai: Shanghai Foreign Language

Harmer, J(1998). How to Teaching English. Longman.

Hutchinson, T. \& Waters, A. (2002). English For Specific Purposes. Shanghai: Shanghai Foreign Language Education Press.

Liu Shulin, et al. (2006). New Concept for English Language Teaching and Learning. Hefei: University

Liu, Yumei \& Xiao Bang. (2007). English Language Teaching: Theory and Practice. Beijing: National

of Science and Technology of China Press.

Swales, J. (ed.). (1985). Episodes in ESP, Pergamon.

Ur, P. A. (1983). Course in Language Teaching: Practice and Theory. Oxford: Oxford University Press.

Widdowson, H.G. (1978). Teaching Language as Communication. Oxford University Press. 
Table 1. Different meanings of the same word in GE and BE

\begin{tabular}{|c|c|c|}
\hline Word & Meaning in GE & Meaning in BE \\
\hline minute & $\begin{array}{l}\text { one sixth part of an hour, equal to } 60 \\
\text { seconds }\end{array}$ & $\begin{array}{l}\text { a brief summary or record of what is said and } \\
\text { decided at a meeting; make a mote of sth. in an } \\
\text { official memo }\end{array}$ \\
\hline round & shaped like a circle or a ball & $\begin{array}{l}\text { (of a meeting) in which the participants meet more } \\
\text { or less as equals }\end{array}$ \\
\hline principal & $\begin{array}{l}\text { person with the highest authority in an } \\
\text { organization, esp in certain schools and } \\
\text { colleges }\end{array}$ & $\begin{array}{l}\text { (finance) money lent or invested on which interest } \\
\text { is paid; capital sum }\end{array}$ \\
\hline liquidate & pay or settle & $\begin{array}{l}\text { close down (a business) and divide up the proceeds } \\
\text { to pay its debts }\end{array}$ \\
\hline portfolio & $\begin{array}{l}\text { flat case for carrying loose papers, } \\
\text { documents, drawings, etc }\end{array}$ & set of investments owned by a person, bank \\
\hline composition & $\begin{array}{l}\text { thing composed, eg a piece of music, a } \\
\text { poem or a book }\end{array}$ & (of business) paying off debt, liquidating \\
\hline disposal & action of getting rid of sth & deal with or sell a bankrupt company \\
\hline turnover & face in another direction by rolling & $\begin{array}{l}\text { amount of business done by company within a } \\
\text { certain period of time } \\
\text { rate at which workers leave a company, etc and are } \\
\text { replaced }\end{array}$ \\
\hline outstanding & exceptionally good; excellent & not yet paid, done, resolved, etc. , an $\sim$ cheque \\
\hline acquisition & action of acquiring & $\begin{array}{l}\text { Action of taking over another company; } \\
\text { merger and Acquisition (M\&A) }\end{array}$ \\
\hline draft & $\begin{array}{l}\text { a rough written version of sth that is not in } \\
\text { its final form }\end{array}$ & a written order to a party to pay money to $\mathrm{sb}$ \\
\hline cove & to include & to protect sb against loss, injury, etc. by insurance \\
\hline
\end{tabular}

